\title{
Histological and histomorphometric studies on the cerebellar cortex and silver stained nucleolus organizer regions of Purkinje neurons in chronic morphine-treated rats
}

\author{
Ilhami Celik ${ }^{1 *}$, Muzaffer Seker ${ }^{2}$, and Ahmet Salbacak ${ }^{3}$ \\ 'Department of Histology and Embryology, Veterinary Faculty, Selcuk University, Kampüs, Konya. Turkey \\ ${ }^{2}$ Department of Anatomy, Meram Medical Faculty, Necmettin Erbakan Konya University, Konya, Turkey \\ ${ }^{3}$ Department of Anatomy, Medical Faculty, Ordu University, Ordu, Turkey
}

\section{CELIK, I., M. ŞEKER, A. SALBACAK: Histological and histomorphometric studies on the cerebellar cortex and silver stained nucleolus organizer regions of Purkinje neurons in chronic morphine-treated rats. Vet. arhiv 88, 75-88, 2018.}

\section{ABSTRACT}

The effects of chronic morphine administration on the rat cerebellum and silver stained nucleolus organizer regions in Purkinje cells were investigated by means of histological, histochemical and histometrical techniques. Thirty-two young (30-32 days of age) Wistar rats (equal numbers of both genders) were randomly divided into 2 groups, as control and morphine-treated, each having equal numbers of both genders, a total of 16 animals. The control animals were injected subcutaneously with $1 \mathrm{~mL} / \mathrm{kg}$ physiological saline, and the morphine-treated rats received $5 \mathrm{mg} / \mathrm{kg}$ morphine hydrochloride subcutaneously at daily intervals for 30 days. The thickness of the molecular and granular layers of the cerebellum, the diameters of the nuclei and nucleoli of cerebellar Purkinje neurones, and the number and size of the silver staining nucleolus organizer regions of the Purkinje cell nuclei were determined histomorphometrically. The morphine administration caused slight histological changes in the cerebellum. The molecular layer thickness of the cerebellum was significantly $(\mathrm{P}<0.05)$ reduced, and the decrease was mainly in the male animals. In contrast, the layer thickened insignificantly in the morphinetreated females. The granular layer thickened slightly but insignificantly in both genders of the morphinetreated group. The Purkinje cell count significantly decreased with morphine treatment. Nucleus size did not change with morphine treatment. However, morphine-treated animals had smaller nucleoli. It was concluded that morphine treatment caused significant histomorphological changes in the cerebellar cortex in a sexually dimorphic manner.

Key words: morphine; rat cerebellum; Purkinje neurones

\footnotetext{
*Corresponding author:

Prof. Dr. Ilhami Celik, Selcuk University, Veterinary Faculty, Department of Histology and Embryology, 42031, Kampüs/ Konya, Turkey, Fax: +90 332241 0063; E-mail: icel@selcuk.edu.tr
} 
I. Celik et al.: Studies on the cerebellar cortex and silver stained nucleolus organizer regions of Purkinje neurons

\section{Introduction}

Morphine has widely been used in the control of pain. It is also one of the opiates which have been a matter of serious concern in drug abuse. Little is known about the detrimental effects of morphine exposure on the cerebellar functions and histology. The results of SHAILENDRA and BHARGAVA (1997) showed that administration of morphine caused an initial decrease in nitric oxide synthase (NOS) activity in the cerebellum, midbrain, cortex and the remainder of the brain, as well as the spinal cord of rats. Nitric oxide (NO) is known as an important neuronal messenger.

HAUSER (1992) found a significant reduction in DNA synthesis by external granular layer (EGL) neuroblasts in a 10-day-old rat cerebellum in the presence of 1 $\mu \mathrm{M}$ morphine, and concluded that morphine could directly regulate the growth of the developing cerebellum by inhibiting neuroblast proliferation within the EGL. In a later study, HAUSER et al. (1994) showed that morphine significantly decreased Purkinje cell survival at higher concentrations, by decreasing the cells' survival. The researchers concluded that morphine can affect Purkinje cell differentiation and survival, and there is a critical period during development when Purkinje cells are especially vulnerable to the effects of morphine. NAPPER and WEST (1995) reported that the cell loss was permanent.

RIMANÓZCY et al. (2001) have suggested that male rats are less sensitive to prenatal morphine exposure. Their findings also showed that prenatal morphine exposure has no effects on the binding characteristics of mu-opioid receptors (MORs) in adult male rats. VATHY et al. (1995) also showed that development of both norepinephrine and dopamine neurotransmitter systems in the hypothalamus, preoptic area, striatum, and cerebellum was diminished in rats descending from parents treated with $10 \mathrm{mg} / \mathrm{kg}$ morphine twice a day during gestation, in a sexually dimorphic manner.

The nucleolus organizer regions (NORs) are the loops of DNA containing ribosomal RNA genes, and these genes are transcribed by RNA polymerase-I and ultimately direct ribosome formation and protein synthesis (SCHEDLE et al., 1992). The NORs are visualized as black dots by the silver colloid technique, and are also known as silver staining nucleolus organizer regions (AgNORs) (LEONG and GILHAM, 1989). WACHTLER et al. (1986) showed that phytohemagglutinin (PHA) stimulation of T lymphocytes resulted in higher nucleolar activity. This result reflects the active RNA synthesis occurring in the stimulated cell. MIRRE and KNIBIEHLER (1982) also claimed that multiplication of fibrillar centres (FCs) in the cell nucleoli, and also the increase in their volume in relation to the enlargement of the reticulated nucleoli of testicular Sertoli cells, could be a result of the synthetic activity of the cell.

In this study, the effects were investigated of chronic morphine administration on the histology of rat cerebellum and AgNOR activity in Purkinje cells by means of histological, histomorphometric and histochemical techniques. 
I. Celik et al.: Studies on the cerebellar cortex and silver stained nucleolus organizer regions of Purkinje neurons

\section{Materials and methods}

Thirty-two young (30-32 days of age) Wistar rats (equal numbers of both sexes) were randomly divided into 2 groups, as control and morphine-treated, each having 16 animals. The animals were housed individually in cages located in a pathogen free, temperature- and humidity-controlled colony room, maintained under a 12-hour daynight illuminating cycle, with free access to food and water. Prior to the experiment, the animals were prepared for manipulation during a 1-week habituation period in the Experimental Medicine Research and Application Centre of the Medical Faculty, N. E. Konya University. This experimental project was approved by the Animal Use Committee of the N. E. Konya University and all the animals were treated in accordance with national and local animal welfare legislation, which is based on European Council Directive.

The first group of animals served as controls and were injected subcutaneously with $1 \mathrm{~mL} / \mathrm{kg}$ physiological saline $(0.9 \% \mathrm{NaCl})$. Morphine hydrochloride, at a dose of $5 \mathrm{mg} / \mathrm{kg}$ in $1 \mathrm{~mL} / \mathrm{kg}$ volume of physiological saline, administrated to the animals in the morphinetreated group, at daily intervals for 30 days. At the end of the administration, the animals were euthanized by an overdose $(100 \mathrm{mg} / \mathrm{kg})$ of sodium pentobarbital. The cerebellum of each animal was totally removed and fixed in phosphate buffered $(0.1 \mathrm{M}, \mathrm{pH} 7.4)$ formalsaline, dehydrated in a graded series of ethyl alcohol, and embedded in paraffin for sectioning. From each tissue block, 30 coronal sections were taken by discarding every other section, and 10 of the sections were stained with either three chrome or Luxol fast blue-cresyl violet stains (CULLING et al., 1992). AgNORs in the Purkinje neurone nuclei were demonstrated on the remaining 10 sections of each block (LEONG and GILHAM, 1989). Light microscopic specimens were examined under a Nikon Eclipse E-400 light microscope (Nikon Corporation, Japan) equipped with a digital imaging system and image analysis software (BS200 PRO, BAB Soft, Turkey).

The thicknesses of the molecular and granular layers of the cerebellar cortex of the cerebellar folia I-X were determined on digital images of 3 regions of each folium: the surface, lateral continuation of the layer facing the fissures and sulci, and the base of each fissure (Fig. 1). Mean values were calculated from the data. The number of Purkinje cells in a unit length $(486 \mu \mathrm{m})$ of the ganglionic layer was counted in the digital images. The mean nucleus and nucleolus diameters of the Purkinje neurones were determined by duplicate diagonal measurements on 100 Purkinje cell nuclei with definite nucleoli, on the digital images. The number and size of AgNORs were determined in a similar manner.

The results were expressed as mean values. The data for the cerebellar layer thickness, nucleus and nucleolus diameters, and the size of the silver staining nucleolus organizer regions (AgNORs) were statistically analysed with one-way ANOVA, whereas the AgNOR count data was analysed with the Mann-Whitney test, using a standard computer 
I. Celik et al.: Studies on the cerebellar cortex and silver stained nucleolus organizer regions of Purkinje neurons

program (SPSS 10.0, 1997, SPSS Inc, USA). The significance of the differences between the groups was determined.

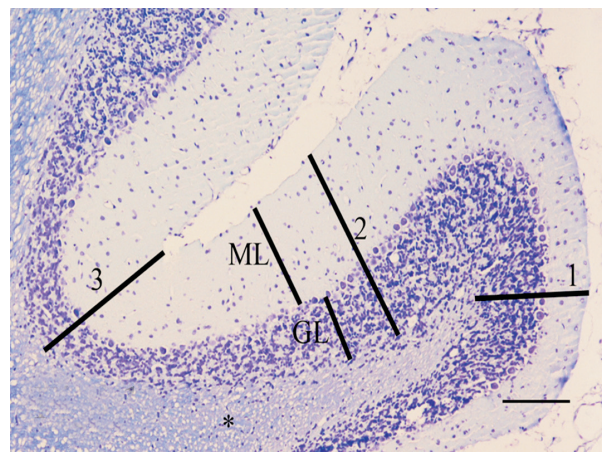

Fig. 1. A mid-sagittal section of the cerebellum of a control male. The measurements were performed on the midsagittal section of the cerebellum. 1) Cortical thickness at folium surface 2) Cortical thickness facing at fissure, 3) Cortical thickness at fissure base, ML) Molecular layer, GL) Granular layer, *) Cerebellar medulla, Luxol fast cresyl blue violet staining, scale bar $=150 \mu \mathrm{m}$.

\section{Results}

Cerebellar histology of the control and morphine-treated animals was quite similar at light microscopic level (Figs. 2A-B).
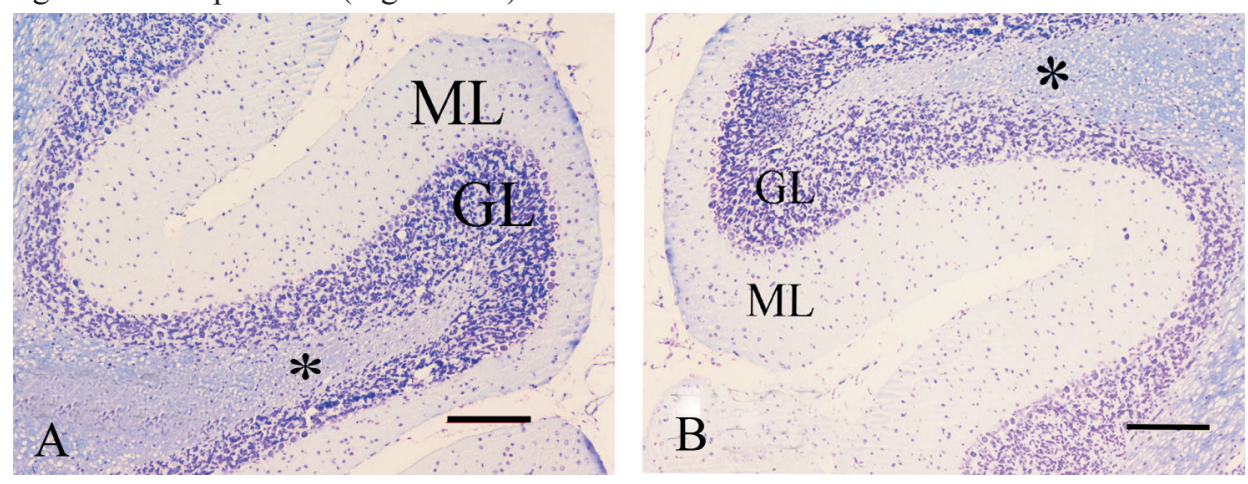

Fig. 2A-B. Sections of the cerebellum of a control male (A) and a control female (B). Similar histology of the cerebellar layers of both genders is clearly seen. ML) Molecular layer, GL) Granular layer of cerebellar cortex, *) Cerebellar medulla. Luxol fast cresyl blue violet stain, scale bar $=160 \mu \mathrm{m}$.

The cerebellar cortex of the control males was thicker than that of the females. Morphine treatment decreased the overall thickness of the cerebellar cortex. Morphine 
treatment resulted in a significant $(\mathrm{P}<0.05)$ reduction of molecular layer thickness in the males, but a slight but insignificant $(\mathrm{P}>0.05)$ thickening in the females. The mean molecular layer of the morphine-treated group was significantly $(\mathrm{P}<0.05)$ thinner than that of the control group. The granular layers of the groups had quite similar $(\mathrm{P}>0.05)$ thickness, and morphine administration did not cause any change in the granular layer thickness (Fig. 3).

Thickness of the cerebellar layers of the groups $(\mu \mathrm{m})$

- Control

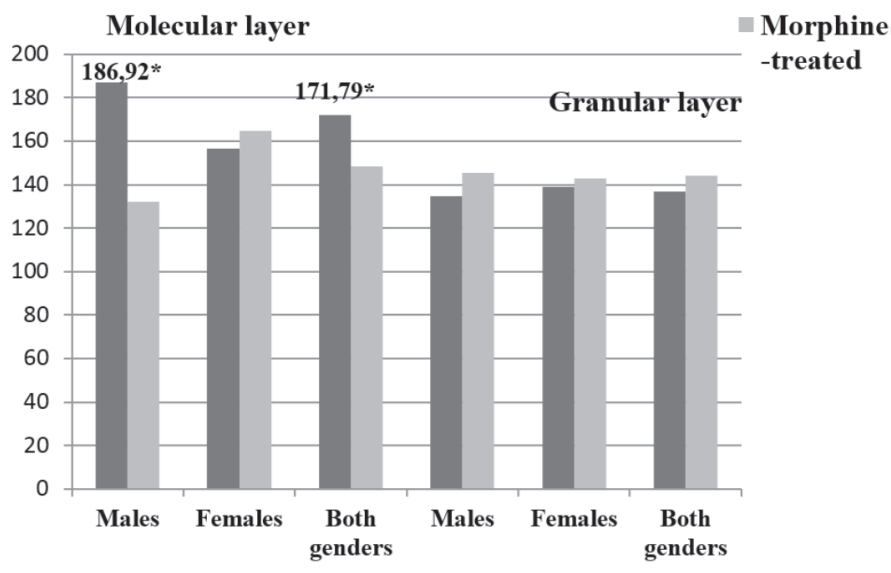

Fig. 3. Mean thickness of the molecular and granular layers of the cerebellum of the groups. Molecular layer thickness significantly reduced in morphine-treated group. Morphine treatment did not cause significant changes in granular layer thickness of either males or females.

The control females (Figs. 4A-B) had more Purkinje cells in the unit length $(486 \mu \mathrm{m})$ of the ganglionic layer than the males. The Purkinje cell count was significantly $(\mathrm{P}<0.05)$ reduced in both genders of the morphine-treated group (Figs. 8A-B and 5).

The control males had a larger Purkinje cell nucleus than the control females. Morphine treatment significantly $(\mathrm{P}<0.05)$ increased the Purkinje cell nucleus size in the males, whereas it was significantly $(\mathrm{P}<0.05)$ reduced in the morphine-treated females. In term of the mean values of both genders, morphine treatment did not cause any change in the nucleus size. In the control group, the females had larger nucleolus than the males. Morphine-treated animals had smaller nucleoli (Fig. 6). The control males had more AgNORs per nucleus than the control females. The AgNOR count of the group given morphine significantly $(\mathrm{P}<0.05)$ increased. Both females and males reacted to the morphine treatment in a similar manner, by increasing the number of AgNOR. 
I. Celik et al.: Studies on the cerebellar cortex and silver stained nucleolus organizer regions of Purkinje neurons

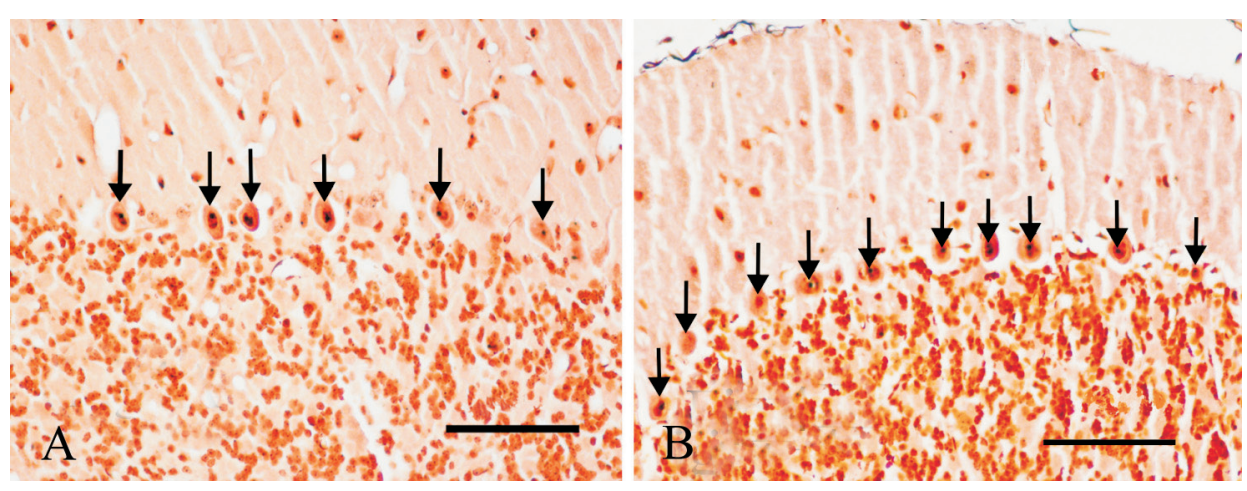

Fig. 4. A-B. Sections the cerebellum of a control male (4A) and a control female (4B). The male has a lower number of Purkinje cells. Arrows) Purkinje cell nuclei. AgNOR stain, scale bar $=50$ $\mu \mathrm{m}$.

Mean Purkinje cell numbers in a unit length of the ganglionic layer

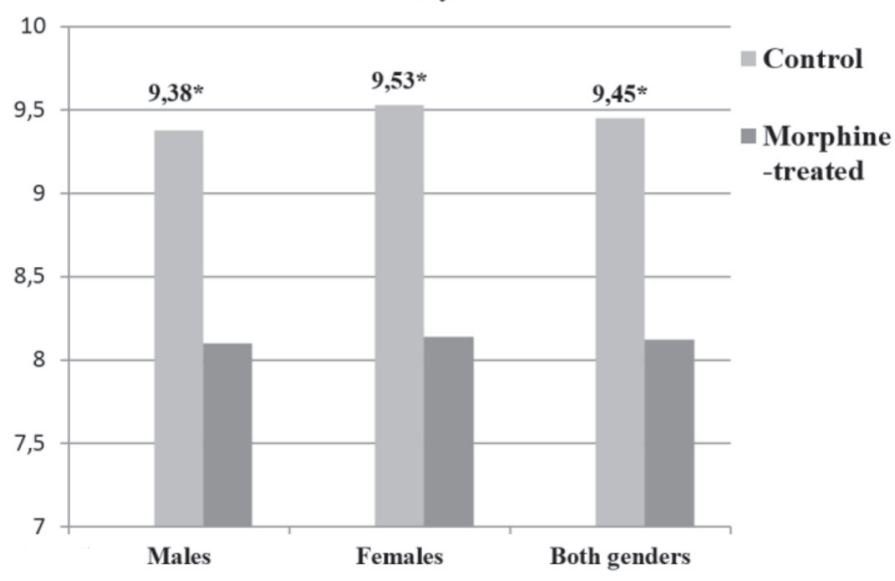

Fig. 5. Mean Purkinje cell counts in a unit length of the ganglionic cerebellar layer of the groups.

Purkinje cell count is reduced in both genders of the morphine-treated group.

The control females had larger AgNORs than the males. The size of AgNOR in the males did not change Morphine treatment did not significantly change the mean AgNOR size in the males. Nevertheless, the females responded with a significant $(\mathrm{P}<0.05)$ reduction in AgNOR size to morphine treatment. The mean AgNOR size of the morphinetreated group was significantly $(\mathrm{P}<0.05)$ reduced (Figs. 7 and 8A-B). 
I. Celik et al.: Studies on the cerebellar cortex and silver stained nucleolus organizer regions of Purkinje neurons

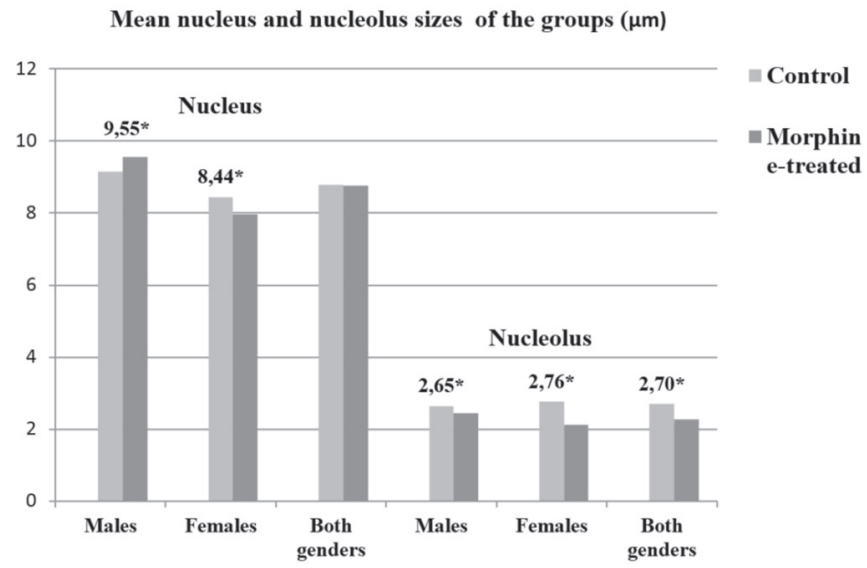

Fig. 6. Mean nucleus and nucleolus sizes of the Purkinje cells of the groups. Morphine-treated males have a larger Purkinje cell nucleus, whereas in the females the nucleus size is smaller. Morphine treatment did not change nucleus size. Morphine-treated animals have smaller nucleoli.

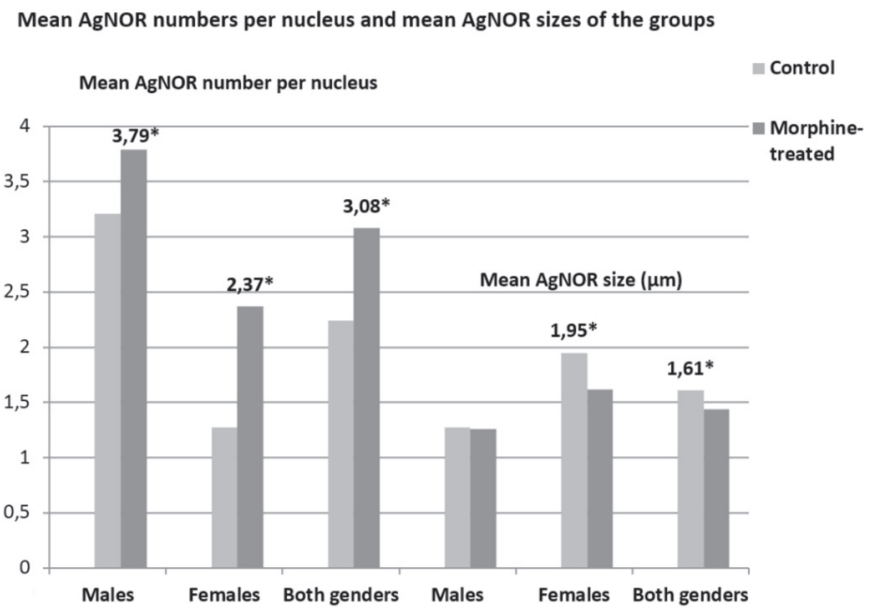

Fig. 7. Mean AgNOR count and AgNOR size of the cerebellar Purkinje cells of the groups. Morphine treatment increased AgNOR count per cell nucleus. The treatment did not change mean AgNOR size in the males, whereas the treatment significantly reduced AgNOR size. 

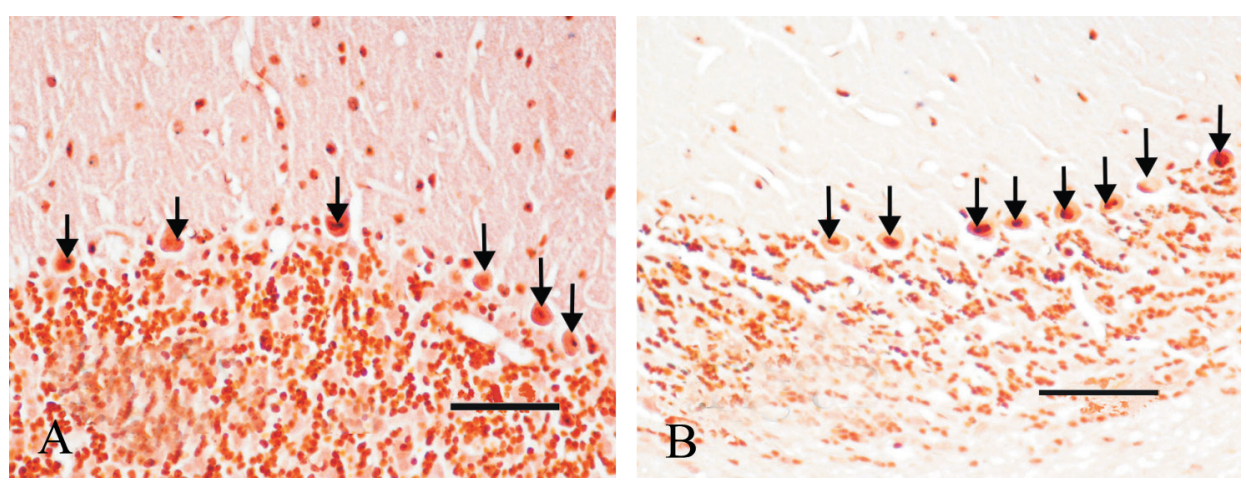

Fig. 8A-B. Sections of the cerebellum of a morphine-treated female (8A) and morphine-treated male (8B). The female has lower Purkinje cell count in the ganglionic layer. AgNOR stain, scale bar $=50 \mu \mathrm{m}$.

\section{Discussion}

The cerebellum is referred to as the "little brain" or as a "neuronal machine" and it coordinates many functions of the brain, mainly motor behaviour, eye movement, conditioning, respiration, and cognition (SAAB and WILLIS, 2003). The cerebellum also mediates detection of sensory discrepancy and plays a crucial role in nociception. Following peripheral nociceptive stimulation, cerebellar activity increases in humans. The anterior part of the cerebellum is a target in rats for the effect of morphine on nociception of the organ (DEY and RAY, 1982). The Purkinje cells of the organ encode nociceptive information that is subsequently decoded by the deep cerebellar nuclei, the brain stem, and the spinal cord or the brain. The cells are also the final decoders of information in essential clues for cerebellar physiology. ZAGON and McLAUGHLIN (1986) investigated the role of endogenous opioid systems in rat cerebellar development by utilising naltrexone, a potent opioid antagonist. They reported that $50 \mathrm{mg} / \mathrm{kg}$ naltrexone had a stimulatory action on cerebellar development, whereas $1 \mathrm{mg} / \mathrm{kg}$ naltrexone had an inhibitory influence in 21 day-old rats. The characteristics of the $50 \mathrm{mg} / \mathrm{kg}$ naltrexone group included increases in cerebellar dimensions and neuronal cell count. The content, size and structural changes were consistent with acceleration in growth and differentiation.

The morphometric results of this study indicated that morphine treatment caused striking changes in the thickness of different regions of the cerebellar cortex in a sexually dimorphic manner. The overall thickness of the molecular layer in the males decreased significantly with morphine treatment, whereas it increased slightly but insignificantly in the females. The overall thickness of the molecular layer was significantly reduced with morphine treatment, regarding both genders. In contrast, the thickness of the granular 
layer increased slightly in the morphine treated group. The results of the present study might show that chronic morphine exposure causes morphometrical changes in different regions of the cerebellar cortex in a sexually dimorphic manner. Moreover, males were more sensitive to the destructive effects of morphine. HAUSER et al. (2000) reported that morphine could block the proliferation of neuroblasts in a molecular layer by preventing DNA synthesis. LORBER et al. (1990) showed that acute opioid exposure blocks the proliferation, differentiation, and survival of neuroblasts and astroglia of the cerebellum. Reduction of the Purkinje cell count in chronic morphine users has been reported (OEHMICHEN et al., 1996). Morphine treatment significantly reduced the thickness of the Purkinje cell layer, and the reduction might reflect decreased Purkinje cell size (GOLALIPOUR and GHAFARI, 2012). Moreover, morphine has been reported to reduce Purkinje cell proliferation and differentiation, and to increase the Purkinje cell death in the cerebellum, as did heroin (THOMAS et al., 1998). Neurone death might be triggered by the N-methyl-D-aspartate receptor-caspase pathway (MAO et al., 2002), damage of the mitochondria (Van TONDER, 2007) or a decrease in calbindin protein, a neuroprotective agent (KIM et al., 2008).

GOLALIPOUR and GHAFARI (2012) studied the toxic effects of morphine sulfate in the adult cerebral cortex and one-day neonatal cerebellum. Administration of morphine sulfate before and during pregnancy, and during lactation caused Purkinje cell loss, and reduced cell size in 18- and 32-day-old infant mice. The toxic effects of morphine continued on the Purkinje cells of the cerebellum even after the lactation period. Morphine sulfate administration can also cause neurotoxic effects on the cerebellar and cerebral cortex by reducing both cortical thickness and the number of neurons in the developing fetal central nervous system (SADRAIE et al., 2008), also significantly reducing the Purkinje cell count (BEKHEET et al., 2010). Purkinje cells in morphine treated animals might be lost by apoptosis and/or necrosis (HAUSER et al., 1994). The morphometric results of the present study showed that morphine-treatment significantly decreased the Purkinje cell count in a unit length of the ganglionic layer in both genders in a similar manner. HAUSER (1992) found that DNA synthesis in neuroblasts is significantly depressed in the presence of $1 \mu \mathrm{M}$ morphine, and it could directly regulate the growth of the developing cerebellum by inhibiting neuroblast proliferation within the external granular layer. In a later study, HAUSER et al. (1994) reported that morphine caused significant detrimental effects on Purkinje cell development in vitro. The researchers (HAUSER et al., 1994) determined that morphine decreased Purkinje cell count at high concentrations $\left(\mathrm{EC}_{50}=3.6 \times 10^{-5} \mathrm{M}\right)$, in organotypic cultures of the mouse cerebellum, by decreasing the cells' survival.

The results of SHAILENDRA and BHARGAVA (1997) showed that morphine administration caused an initial decrease in nitric oxide synthase (NOS) activity in the cerebellum, midbrain, cortex and the remainder of the brain, as well as the spinal cord 
I. Celik et al.: Studies on the cerebellar cortex and silver stained nucleolus organizer regions of Purkinje neurons

of rats. Nitric oxide (NO) is known as an important neuronal messenger. It is also wellknown that NO redox species induce cell death in various cells. Purkinje cell losses from the cerebella of morphine treated animals might have arisen from the toxic effects of NO redox species. Because activation of NO increased the production of cGMP, BHARGAVA and CAO (1997) suggested that NOS inhibitors affect the development of tolerance to morphine and morphine-opioid receptor agonists. Additionally, SHAILENDRA and BHARGAWA (1997) assumed that the changes in central NOS activity under morphine treatment appear to be mediated by opioid receptors. The morphometrical results of this study showed that morphine treatment affected the nucleus size of Purkinje cells in a dimorphic manner. The morphine treatment significantly increased the nucleus size in the males, whereas it decreased in the females. Nevertheless, the mean nucleus size of both genders was significantly reduced in the morphine-treated group. The nucleolus size was also reduced significantly in the morphine-treated group.

Fibrillar centres (FCs), dense fibrillar components (DFCs) and granular components (GCs) are recognised in the cell nucleoli on electron microscopy (GOESSENS and LE POINT, 1979). Although the number of FCs does not indicate the exact numbers of nucleolus organizer regions (NORs), silver staining NORs (AgNORs) visualised on light microscopy are assumed to be the FCs of the cell nucleolus seen on the electron microscopic level (MIRRE and KNIBIEHLER, 1982). The size of the silver deposit on the NOR is thought to be positively correlated to the protein synthesis activity of the cell (WACHTLER et al., 1986). Thus, the size and number of AgNORs in a given cell are thought to be positively correlated with the degree of transcriptional activity (ZATSEPINA et al., 1988), believed to reflect nucleolar activity, and also to be related to cellular proliferation (CABRINI et al., 1992; MAO et al., 2002).

In this study, the AgNORs of the control females were larger than those of the control males. The lowest AgNOR counts were seen in the females in both the control and morphine-treated groups. The number of AgNORs significantly increased, but conversely their size decreased in the morphine-treated group. Because the argyrophil proteins in the NORs play important roles in rRNA transcription and ribosomal biogenesis, their number may well indicate the state of activity of a cell with respect to its ribosome synthesis. WACHTLER et al. (1986) showed that phytohemaglutinin (PHA) stimulation of $\mathrm{T}$ lymphocytes resulted in higher nucleolar activity. This result reflects the active RNA synthesis occurring in the cell. MIRRE and KNIBIEHLER (1982) also claimed that multiplication of fibrillar centres (FCs) in the cell nucleoli, and also an increase in their volume in relation to the enlargement of the reticulated nucleoli of the Sertoli cells, could be a result of the activation of more rRNA cistrons. The observation of a significant increase in AgNOR activity might possibly relate to stimulation of Purkinje cells. Sexual dimorphism was reported in rats exposed in utero to morphine (VATHY et al., 1995). 
I. Celik et al.: Studies on the cerebellar cortex and silver stained nucleolus organizer regions of Purkinje neurons

The results of this study revealed that subcutaneous morphine administration at a dose of $5 \mathrm{mg} / \mathrm{kg}$ for 30 days caused significant changes to the thickness of the cerebellar cortex and Purkinje cells. Based on the results, it was concluded that morphine treatment causes significant histomorphometrical changes to the cerebellar cortex and cellular changes in Purkinje cells, in a sexually dimorphic manner.

\section{References}

BEKHEET, S. H., S. A. SAKER, A. M. ABDEL-KADER, A. E. YOUNIS (2010): Histopathological and biochemical changes of morphine sulphate administration on the cerebellum of albino rats. Tiss. Cell 42, 165-175.

DOI:10.1016/j.tice.2010.03.005

BHARGAVA, H. N., Y. J. CAO (1997): Effect of chronic administration of Morphine, U-50, 488H and (D-Pen2, D-Pen5) enkephalin on the concentration of cGMP in Brain regions and spinal cord of the mouse. Peptides 10, 1629-1634.

DOI: 10.1016/S0196-9781(97)00233-7

CABRINI, R. L., A. E. SCHWINT, A. MENDEZ, F. FEMOPASE, H. LANFRANCHI, M. E. ITOIZ (1992): Morphometric study of nucleolar organizer regions in human oral normal mucosa, papiloma and squamous cell carcinoma. J. Oral. Pathol. Med. 21, 275-279.

DOI: 10.1111/j.1600-0714.1992.tb01010.x

CULlinG, C. F. A., R. T., ALLISON, W. T., BARR, P. BRADBURY, K. C. GORDON (1992): Connective tissues and stains. In: Theory and practice of histological techniques. (Bancroft, J. D., A. Stevens, Eds.). $3^{\text {rd }}$ edit. Churchill Livingstone UK, pp. 119-141.

DEY, P. K., A. K. RAY (1982): Anterior cerebellum as site for morphine analgesia and poststimulation analgesia. Indian J. Phys. Pharm. 1, 3-12.

GOESSENS, G., A. LE POINT (1979): The nucleolus-organizing regions (NORs): recent data and hypotheses. Biol. Cell. 35, 211-220.

GOLALIPOUR, M. J., S. GHAFARI (2012): Purkinje cells loss in off spring due to maternal morphine sulfate exposure: a morphometric study. Anat. Cell Biol. 45, 121-127.

DOI: $10.5115 / \mathrm{acb} .2012 .45 .2 .121$

HAUSER, K. F. (1992): Morphine regulates DNA synthesis in rat cerebellar neuroblasts in vitro. Brain Res. Dev. 2, 291-297.

DOI: $10.1016 / 0165-3806(92) 90210-\mathrm{N}$

HAUSER, K. F., J. A. GURWELL, C. S. TURBECK (1994): Morphine inhibits Purkinje cell survival and dendritic differentiation in organotypic cultures of the mouse cerebellum. Exp. Neurol. 130, 95- 105.

DOI: 10.1006/exnr.1994.1188

HAUSER, K. F., A. A. HOUDI, C. S. TURBEK, R. P. ELDE, W. MAXSON (2000): Opioids intrinsically inhibit the genesis of mouse cerebellar granule neuron precursors in vitro: 
I. Celik et al.: Studies on the cerebellar cortex and silver stained nucleolus organizer regions of Purkinje neurons

differential impact of mu and delta receptor activation on proliferation and neurite elongation. Eur. J. Neurosci. 12, 1281-1293.

DOI: $10.1046 /$ j.1460-9568.2000.01015

KIM, J. S., J. M. KIM, J. A. SON, S. Y. HAN, C. T. KIM, N. S. LEE, Y. G. JEONG (2008): Decreased calbindin-immunoreactive Renshaw cells (RCs) in the lumbar spinal cord of the ataxic pogo mice. Korean J. Anat. 41, 255-263.

LEONG, A. S. Y., P. GILHAM (1989): Silver staining of nucleolar organizer regions in malignant melanoma and melanotic nevi. Hum. Pathol. 20, 257-262.

DOI: $10.1016 / 0046-8177(89) 90133-0$

LORBER, B. A., S. K. FREITAG, J. V. BARTOLOME (1990): Effects of beta-endorphin on DNA synthesis in brain regions of preweanling rats. Brain Res. 531, 329-332.

DOI: 10.1016/0006-8993(90)90795-D

MAO, J., B. SUNG, R. R. JI, G. LIM. (2002): Neuronal apoptosis associated with morphine tolerance: evidence for an opioid-induced neurotoxic mechanism. J. Neurosci. 22, 7650-7661.

MIRRE, C., B. KNIBIEHLER (1982): A re-evaluation of the relationships between the fibrillar centres and the nucleolus-organizing regions in reticulated nucleoli: Ultra structural organization, number and distribution of the fibrillar centres in the nucleolus of the mouse Sertoli cell. J. Cell Sci. 55, 247-259.

NAPPER, R. M., J. R. WEST (1995): Permanent neuronal cell loss in the cerebellum of rats exposed to continuous low blood alcohol levels during the brain growth spurt: a stereological investigation. J. Comp. Neurol. 2, 283-292.

DOI:10.1002/cne. 903620210

OEHMICHEN, M., C. MEISSNER, A. REITER, M. BIRKHOLZ (1996): Neuropathology in nonhuman immunodeficiency virus-infected drug addicts: hypoxic brain damage after chronic intravenous drug abuse. Acta Neuropathol. 91, 642-646.

RIMANÓCZY, Á., R. ŚLAMBEROVÁ, I. VATHY (2001): Prenatal morphine exposure alters estrogen regulation of kappa receptors in the cortex and POA of adult female rats but has no effects on these receptors in adult male rats. Brain Res. 894, 154-156.

DOI: $10.1016 / \mathrm{S} 0006-8993(00) 03326-6$

SAAB, C. Y., W. D. WILLIS (2003): The cerebellum: organization, functions and its role in nociception. Brain Res. Rev. 42, 85-95.

DOI: $10.1016 / \mathrm{S} 0165-0173(03) 00151-6$

SADRAIE, S. H., G. R. KAKA, H SAHRAEI, H. DASHTNAVARD, H. BAHADORAN, M. MOFID, H. M. NASAB, F. JAFARI (2008): Effects of maternal oral administration of morphine sulfate on developing rat fetal cerebrum: a morphometrical evaluation. Brain Res. $1245,36-40$.

DOI: 10.1016/j.brainres.2008.09.052 
I. Celik et al.: Studies on the cerebellar cortex and silver stained nucleolus organizer regions of Purkinje neurons

SCHEDLE, A., M. WILLHEIM, A. ZEITELBERGER, A. GESSL, K. FRAUENDORFER, C. SCHOFER, F. WACHTLER, H. G. SCHWARZACHER, G. BOLTZ-NITULESCU (1992): Nucleolar morphology and rDNA in situ hybridisation in monocytes. Cell Tissue Res. 3, 473480.

DOI: $10.1007 / \mathrm{BF} 00353902$

SHAILENDRA, K., H. N. BHARGAVA (1997): Time course of the changes in central nitric oxide synthase activity following chronic treatment with in the mouse: Reversal by naltrexone. Gen. Pharmacol. 2, 223-227.

DOI: $10.1016 / \mathrm{S} 0306-3623(96) 00416-8$

THOMAS, J. D., C. R. GOODLETT, J. R. WEST (1998): Alcohol-induced Purkinje cell loss depends on developmental timing of alcohol exposure and correlates with motor performance. Brain Res. Dev. Brain Res. 105, 159-166.

DOI: 10.1016/S0165-3806(97)00164-8

Van TONDER, J. J. (2007): Effect of the cardiac glycoside, digoxin, on neuronal viability, serotonin production and brain development in the embryo. MSc Thesis. Pretoria: School of Medicine, Faculty of Health Science, University of Pretoria.

VATHY, I., A. RIMANOCZY, R. C. EATON, L. KATAY (1995): Sex dimorphic alterations in postnatal brain catecholamines after gestational morphine. Brain Res. Bull. 2, 185-193.

DOI: 10.1016/0361-9230(94)00192-4

WACHTLER, F., A. H. HOPMANN, J. WIEGANT, H. G. SCHWARZACHER (1986): On the position of nucleolar organizer regions (NORs) in interphase nuclei. Studies with a new, nonauto radiographic in situ hybridization method. Exp. Cell Res. 167, 227-240.

DOI: $10.1016 / 0014-4827(86) 90219-3$

ZAGON, I. S., P. J. McLAUGHLIN (1986): Opioid antagonist (naltrexone) modulation of cerebellar development: histological and morphometric studies. J. Neurosci. 5, 1424-1432.

ZATSEPINA, O. V., P. V. CHELIDZE, Y. CHENTSOW (1988): Changes in the number and volume of fibrillar centres with the inactivation of nucleoli at erythropoiesis. J. Cell Sci. 91, 439-448.

Received: 2 September 2016

Accepted: 1 March 2017

CELIK, I., M. ŞEKER, A. SALBACAK: Histološko i histomorfometrijsko istraživanje kore malog mozga i srebrom obojenih regija nukleolusne organizacije Purkinjeovih neurona u štakora kronično tretiranim morfinom. Vet. arhiv 88, 75-88, 2018.

\section{SAŽETAK}

Učinci kronične primjene morfina na mali mozak štakora i na srebrom obojene regije nukleolusne organizacije Purkinjeovih neurona istraživani su histološkim, histokemijskim i histometrijskim tehnikama. Trideset i dva mlada Wistar štakora (dob 30 - 32 dana), u jednakom omjeru spolova, metodom slučajnog izbora podijeljena su u dvije skupine s po 16 jedinki u svakoj skupini. Životinjama u kontrolnoj skupini potkožno je primijenjen $1 \mathrm{~mL} / \mathrm{kg}$ fiziološke otopine, dok su životinje u pokusnoj skupini dobile $5 \mathrm{mg} / \mathrm{kg}$ morfin hidroklorida, 
I. Celik et al.: Studies on the cerebellar cortex and silver stained nucleolus organizer regions of Purkinje neurons

potkožno, svaki dan tijekom 30 dana. Za određivanje zadebljanja molekularnih i granulacijskih slojeva maloga mozga, promjera jezgre i nukleolusa Purkinjeovih neurona u malom mozgu te broja i veličine srebrom obojenih regija nukleolusne organizacije Purkinjeovih neurona primijenjena je histomorfometrijska metoda. Davanje morfina izazvalo je blage histološke promjene u malom mozgu. Debljina molekularnog sloja maloga mozga značajno je smanjena $(\mathrm{P}<0,05)$. To je ponajprije bilo izraženo kod životinja muškoga spola, dok je molekularni sloj kod ženki tretiranih morfinom bio tek neznatno zadebljan. Granulirani sloj bio je blago i nesignifikantno zadebljan u oba spola unutar skupine tretirane morfinom. Broj Purkinjeovih stanica značajno je smanjen nakon primjene morfina, dok to nije bio slučaj s veličinom jezgre koja se nije mijenjala. No, životinje koje su dobivale morfin imale su manje nukleole. Zaključeno je da liječenje morfinom uzrokuje značajne histomorfološke promjene u kori maloga mozga, pri čemu važnu ulogu ima spol jedinke.

Ključne riječi: morfin; mali mozak; Purkinjeovi neuroni 